\title{
JUURNAL_RU
}

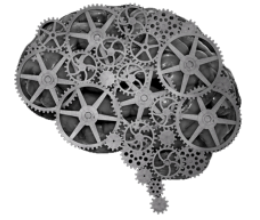

COMPANY GROUP "INTELLEKT"

Григорьянц Т.А. Кемеровский государственный институт культуры Кемерово, Россия

doi: 10.18411/1j2016-5-3-03

\section{Ритмическая структура спектакля: выразительные возможности пластической рифмы}

Любые формы жизни, процессы, события обладают своей ритмической структурой своим ритмом, который представляется своеобразной формой выражения жизни вообще. Ритм «согласно Клагесу, - определяется как «возвращение подобного через одинаковые промежутки времени, в противоположность такту, который является абсолютно точным (математически) повторением равного» [1, с.397].

Безусловна значимость ритма в музыке, искусстве танца, вокальном и литературном творчестве. Для живописи, скульптуры это понятие также актуально. Ритмическая организация структурных элементов сценического произведения - важная составляющая его художественного образа. Трудно переоценить значение и выразительные возможности ритмического рисунка в спектакле с позиций формы, его важность в роли структурной составляющей общего «строения» драматической постановки. $\mathrm{He}$ менее значимым представляется темпо-ритм спектакля как один из важнейших аспектов театроведческого анализа произведения. В драматическом спектакле ритмическую организацию сценического действия можно рассматривать не только как компонент художественного образа, но и как характеристику профессионального мастерства режиссера. Эта способность выражается в мастерстве организовывать выразительные средства и выстраивать отношения 
между ними, которые, также являются средствами выражения, но уже другого уровня. Существуют темпо-ритмы спектакля, сцены, фрагмента, роли. Темпоритм связывает представление о скорости действия с представлением о временных соотношениях между его частями. Таким образом, по мнению Г.В. Морозовой «единицей измерения темпо-ритма сценического действия является темпо-ритм его элементарного отрезка - дробного действия» [2, с.71]. Понятие темпо-ритма сценического действия было введено К.С. Станиславским для определения пространственно-временной организации спектакля. Анализируя работа актера над ролью, автор всемирно известной «системы» приходит к заключению, что «темпо-ритм обладает чудодейственной силой. Это он воздействует на ваше внутреннее настроение..» Более того, «если темпо-ритм взят верно, то правильное чувство и переживание создаются естественно, сами собой. Но, зато, если темпо-ритм неверен, то совершенно так же, на том же месте роли родятся для нас чувство и переживания, которых не исправишь без изменения неправильного темпо-ритма» [3, с.450-451]. Рассматривая становление роли, развитие ее внутреннего и внешнего рисунка далее, К.С. Станиславский приходит к заключению, что темпо-ритм важен не только для естественного создания «правильного» чувства, оказывается: «темпо-ритм действия может интуитивно, прямо, непосредственно подсказывать не только соответствующее чувствование и возбуждать переживания, но и помогать созданию образов» [3, с.451]. Но и это еще не все, «оказывается он (темпо-ритм) может подсказывать не только образы, но и целые сцены!» [3, с.453].

В искусстве режиссера темпо-ритмический каркас будущего спектакля создается не сразу, несмотря на то, что предполагается и видится автором еще на первом этапе. Пространственно-временной рисунок появляется в процессе анализа и определения сквозного действия постановки. Рождается художественный образ, который постепенно реализуется в сценическом тексте постановки. В процессе репетиций многое уточняется, иногда меняется, появляются новые детали, идея режиссера воплощается в «материале». 
Искусство режиссуры обладает, наверное, самым большим арсеналом выразительных средств. В настоящее время в театральных постановках представлены практически все существующие виды искусств и технического творчества. Никого уже не удивишь введением и использованием на сцене компьютерных технологий, звуковых и световых эффектов, создаваемых современной техникой, инсталляциями, экспериментами фото и видио техники нового поколения. Но, несмотря на введение новых «способов художественного выражения» в процесс материализации идей постановщика, основным «инструментом», при помощи которого создается и воплощается действие, всегда был и остается актер.

Темпо-ритмический рисунок сценического произведения фиксируется и проявляется во всех выразительных средствах, используемых в спектакле. Некоторые из них ритмически организованы «жестко», например, сценографическое оформление, костюмы персонажей. Другие - существуют более «свободно». Сложнее всего удерживать определенный ритмический рисунок исполнительскому ансамблю. Вопрос не в отсутствии ответственности у актеров. Прежде всего, как любой живой человек, актер обладает природной пластичностью, которая «не позволяет» произносить один и тот же жест или слово дважды с одинаковой интонацией, в одной и той же пространственновременной конструкции. Непрерывность и текучесть существования человека в этой ситуации дают возможность лишь формально повторять намеченное режиссером. Необходимо заметить, что иногда эта «приблизительность» очень высока. Но, «жизненная кантилена» не единственное обстоятельство, определяющее артиста как самое не стабильное в отношении фиксации ритмической схемы спектакля выразительное «средство». В процессе работы над ролью огромное значение играет профессионально поставленная пластичность. Эта характеристика подразумевает способность к импровизации, обладая которой актер свои действия максимально приближает к жизни. Чем виртуознее импровизация, тем интереснее игра исполнителя, которая не только 
захватывает зрителя, но и заставляет его верить в происходящее на сцене. Именно ансамбль исполнителей является главным материалом и инструментом в создании живого пульса сценического произведения. Можно предположить, что некоторая нестабильность пластического текста спектакля (то есть, сиюминутно рождаемого действия) и дает те необходимые характеристики, благодаря которым искусство театра (в отличие от искусства кино, например) считается живым, более искренним и выразительным.

Одним из способов проявления ритма в сценическом произведении является пластическая рифма. Понятие «рифма» в большей степени соотносится с литературой, литературоведением, в частности с одним из его разделов теорией литературы. «Рифма» происходит от греческого слова, означающего «соразмерность». В организации стиха, как части художественной целостности, рифма играет важную роль, «она связана со звуком, ритмом, лексикой, интонацией и синтаксисом» [4, с.324].

Среди многих функций рифмы для нас, в ситуации соотнесения с пластической рифмой спектакля, особый интерес вызывает лексическая функция, которая заключается в том, что «она выделяет слова, связанные звуковым повтором, и тем самым усиливает ассоциативную сферу стиха» [4, с.324]. В переводе на язык сценического действия, пластическая рифма выделяет отдельные сцены, либо фрагменты сцен, усиливая этим «ассоциативную сферу» спектакля. Повторы здесь могут быть мизансценические, пластические (решение отдельных эпизодов в танце, например), может иметь место повтор пластической партитуры отдельного персонажа, либо части этой партитуры и многое другое. Важным в этой ситуации является выбор лексики - способ материализации, кроме этого, существенную роль играет «рисунок» и «объем» рифмы, которые, в конечном счете, при правильном решении дают ожидаемый результат, возникающий только в процессе движения действия, a завершающейся по окончанию спектакля. 
Понятие «пластика спектакля» - сложносоставное и сложно организуемое. В данной статье мы коснемся создания и функционирования пластической телесной рифмы, то есть художественного приема, организованного телесностью исполнителей. Чаще всего подобные сцены решаются различными хореографическими номерами и импровизациями. Реже пластическая рифма организуется в пантомиме, трюковой пластике, акробатических зарисовках.

По нашему мнению, одним из образцов «работы» пластической рифмы на режиссерский замысел мы находим в спектакле О.Р. Пермякова «Васса», поставленного в 2007г. в Кемеровском областном театре драмы им. А.В. Луначарского по пьесе А.М. Горького «Васса Железнова». Здесь пластическая рифма присутствовала уже в период формирования режиссерского замысла и уже тогда была его частью. Она была представлена автором в образе вокзала. Форма вокзала с ее суетой, движением, эклектикой жизненных ситуаций создавала атмосферу ожидания, призрачности существования человека, и даже некоторой тоски. Образ вокзала рассматривался режиссером как возможность отстраненного и отдаленного взгляда на страшную, уродливую реальность. Пластические картинки вокзала, таким образом, по мысли постановщика, служили не только своеобразным «напоминанием» о бренности существования, но и «отбивали» собой чудовищные образы повседневности. Кроме этого, на наш взгляд, этот прием оказался внутри другого, в искусстве режиссуры он определяют как повтор. Использование зарифмованных пластических фрагментов, существующих внутри постановочного приема - «повтор», явилось особенностью композиции данной режиссерской работы.

Сценой «призрачного вокзала» начинается спектакль. Зритель видит, как в глубине в серо-голубом мраке оживает пространство, оно наполняется различными фигурами. Эти одинокие «люди», глубоко погруженные в свою личную драму, всегда вместе, на одной платформе; складывается впечатление, что они являются неотъемлемой частью этого вокзала. «Люди с платформы» ожидают чего-то, атмосферой напряженного ожидания пронизан весь спектакль. 
Движения вокзальных персонажей слегка замедленны, они как бы плывут в пространстве сцены, несколько одинаковы в жестах, но при этом сохраняют свою индивидуальность. «Люди на платформе» существуют в своем темпоритме, они организуют собой особую атмосферу. С одной стороны, пластические «картинки» рисуют мир небытия, с другой стороны, находясь в контрасте с основным действием спектакля, они создают ощущение зыбкости и хрупкости громкой и цветной повседневности людей, выхваченных обстоятельствами из огромного окружающего мира и представленных на сцене.

$\mathrm{He}$ менее выразительно «зарифмованны» пластические картины в спектакле К. Шахмардана «Макбет» по мотивам одноименной пьесы В. Шекспира (Кемеровский областной театр драмы им. А.В. Луначарского, 2016г). Режиссер и автор данной сценической версии вводит рефреном сцены ведьм, которые «звучат» то предостережением, то эхом уже произошедших событий. «Размытый» хореографический рисунок одной сцены плавно перетекает в основное действие, которое внезапно «перебивается» «рапидным» существованием ведьм-предсказательниц. Пластические фрагменты погружают зрительскую аудиторию в атмосферу напряженного ожидания, тревоги. Плавные, раскрывающиеся в объеме движения прорицательниц, как туман медленно наполняют место события, предвещая череду печальных событий, их неизбежность.

Использование такого художественного приема, как пластическая рифма, способ ее воплощения, выбор пластической лексики - все это является характеристикой творческого почерка режиссера. В спектакле «Васса» режиссером была поставлена задача - найти пластический эквивалент необходимому эмоциональному состоянию. «Картины на вокзале» стали материальным основанием необходимой атмосферы. Важным представляется то, что изначально автор принял решение создавать пластические рифмы не иллюстративно, а несколько отстраненно. Режиссер постановки считает, что отстраненность и непричастность к сюжету пьесы позволят представить события 
сценической истории более выпукло и объемно. Сюжеты же самих пластических зарисовок выражала, на наш взгляд, основную идею - жизнь не должна быть вечным ожиданием «естественного ухода», при этом нельзя забывать, что к чему бы мы не стремились, как бы мы не пытались обманывать себя и других, наступает минута, которая делает всех равными. В спектакле К. Шахмардана «Макбет» зарифмованные пластические сцены также являются инструментом для создания необходимой интонации в сценической работе. Данные постановки демонстрируют выразительные возможности самих пластических сцен и создаваемого ими ритмического рисунка. Оба спектакля, несмотря на разные способы организации телесного «материала», являются примером воплощения одной из функций пластической рифмы - создание необходимой эмоциональной атмосферы в спектакле.

\section{Литература:}

1. Философский энциклопедический словарь. - М.: ИНФРА-М, 2004. - С.397.

2. Морозова Г.В. Пластическая культура актера: Толковый словарь терминов. - М.: ГИТИС, 1999. - С.71.

3. Мастерство актера в терминах и определениях К.С. Станиславского. - М.: Советская Россия, 1961. - С.450-451.

4. Словарь литературоведческих терминов. - М.: Просвещение, 1974. - С.324. 